\title{
HISTOPATHOLOGICAL STUDY OF SPONTANEOUS SEX-DEPENDENT PROTEIN REABSORPTION DROPLETS IN THE BEAGLE DOG KIDNEY
}

\author{
Yoshihide Koike \\ Division of Toxicology, Japan Seigiken Research Center \\ Hijiri Iwata, Yasuhiko Hirouchi, Kazuo Kobayashi, \\ and Makoto Enomoto \\ Division of Pathology, Biosafety Research Center, Foods, Drugs and Pesticides
}

\begin{abstract}
Sex-dependent protein reabsorption droplets (PRD) were observed in the kidneys of beagle dogs. Seventy-six untreated males and seventy-eight untreated females were examined histologically. Microscopically, two types of PRD were detected in the proximal tubules (P3 segment). One was large and palely eosinophilic, and the other was small and deeply eosinophilic. Ultrastructural features of the large droplets were cytoplasmic vacuoles filled with electron lucent, proteinaceous, fine granular material. The small droplets were irregular clumps of electron lucent material without a boundary membrane. These PRD are likely to arise from intense reabsorption of protein from the urine by tubular cells as evident by histological or ultrastructural forms and response to various staining methods. The incidence of PRD in male beagle dogs was $36.8^{\circ}(28 / 76)$, but there was no PRD in females. The highest incidence of PRD occurred in males 9-11 months of age. Since this finding was seen only in males and since no glomerular changes were evident, it was suggested that male beagle dogs have a low-molecular-weight, sex-dependent urinary protein like $\alpha 2 \mu$-globulin in adult male rats. (J Toxicol Pathol 6: 73 $\sim 80,1993$ ) Key words: Sex difference, Canine kidney, Hyaline droplets, Eosinophilic body, Naturally occurring, Proximal tubules
\end{abstract}

\section{Introduction}

PRD in renal tubular cells have been observed occasionally in humans, domestic animals ${ }^{1}$, rats, and other species ${ }^{2-4}$. These PRD are generally regarded to be the result of intense protein reabsorption of the lysosomes when the glomerular permeability increases ${ }^{l}$. They are classified as either hyaline droplets or eosinophilic bodies. Hyaline droplets are small, vary in size, globular, deeply eosinophilic, and stain positive with periodic acid Schiff reaction (PAS). The eosinophilic bodies seen only in adult male rats, are large, irregular in shape, palely eosinophilic, and stain negative with

小池嘉秀 岩田 聖 廣内康彦 小林和雄 榎本 咀

Accepted for publication : January 3, 1993

Mailing address: Yoshihide Koike, Division of Toxicology, Japan Seigiken Research Center, 95-10, Aoi-cho, Hamamatsu-shi, Shizuoka 433, Japan.

\section{PAS $^{5-7}$.}

Adult male rats have both types of $\mathrm{PRD}^{2,6-8}$. It is believed that they are related to a low-molecular-weight protein in male rats, specifically $\alpha 2 \mu$ globulin $(\alpha 2 \mu)^{9-20} . \quad \alpha 2 \mu$ Nephropathy is recognized as an important toxic syndrome that occurs in male rats following exposure to a variety of volatile hydrocarbons including unleaded gasoline and related materials ${ }^{21-27}$, decalin ${ }^{28-30}, \mathrm{JP}-4$ and JP-5 jet fuel ${ }^{31,32}$ isophorone, 1,4-dichlorobenzene $e^{33}, \mathrm{~d}$-limonene ${ }^{34}, 2,2,4$-trimethylpentane ${ }^{17.35,36}$, trichloroethylene, perchloroethylene, and pentachloroetane ${ }^{37}$. The acute or subchronic phase of the disease is characterized by the accumulation of $\alpha 2 \mu$ in tubular cells. Chronic exposure to these chemicals leads to exacerbation of chronic nephropathy, mineralization of the renal medulla, and finally the induction of the renal neoplasia in male rats $^{8,21,23,27,37-39}$. 
This study has revealed that the PRD, which are similar to those seen in male rats, occurred spontaneously in the proximal renal tubular epithelial cells of male beagle dogs. This study describes the incidence, histopathological and ultrastructural features of these changes.

\section{Materials and Methods}

Seventy-six male and seventy-eight female, control beagle dogs, used in toxicological studies, were examined. Animals of approximately 6 months of age were purchased from Laboratory Research Enterprises, Inc., Michigan, Ages ranged from 7-32 months. Animals were housed individually, in stainless steel cages in rooms maintained between $23-26^{\circ} \mathrm{C}, 50-60 \%$ relative humidity, and a 12 hour light-dark cycle (150-300 lux). The diet contained 21.0 to $26.3 \%$ protein (DS ; Oriental Koubo Co., Tokyo, Lab Chows and Lab Diet 4360 ; Purina Taiyo Pet Hood Co., Chiba). Dogs were given a $250 \mathrm{~g}$ ration of feed per day and were allowed free access to tap water.

Tissue specimens were fixed in $10 \%$ neutral, phosphate-buffered formalin, embedded in paraffin, and cut into $4 \mu$ sections. The sections were stained with hematoxylin and eosin (HE). PAS, oil red O, Sudan black B, Weigert's, Gram's, Masson trichrome, Heidenhein's azan and acid fuchcin orange $G$ (AFOG) techniques were also performed.

Tissue specimens were fixed with $2.5 \%$ glutaraldehyde in $0.1 \mathrm{M}$ phosphate buffer ( $\mathrm{pH} 7.4$ ), post-fixed in $1 \%$ osmium tetroxide in $0.1 \mathrm{M}$ phosphate buffer, and embedded in epoxy resin for electron microscopic examinations. Semithin sections were cut, stained with $1 \%$ toluidin blue, and suitable areas were evaluated for electron microscopy. Thin sections were cut at 60 to $80 \mathrm{~nm}$, stained with uranyl acetate and lead citrate, and examined with a Hitachi $\mathrm{H} 5000$ transmission electron microscope.

\section{Results}

Renal tubular PRD are not visible to the naked eye, but are only detected with the aid of a microscope. The incidence of PRD are presented in Table 1. The criteria for the severity of PRD employed three categories of their distribution; slight : focal or involving a few tubules; moderate: scattered in the outer medulla; marked: diffuse, involving many tubules. The total incidence of PRD in the male was $36.8 \%(28 / 76)$. There were no PRD in the females. The highest incidence $(45.2 \%)$ was seen at the age of nine to eleven months. The incidence of this finding in males 18-19 months of age was somewhat lower than that in males 9-11 months old.

Histological examinations revealed two types of renal tubular PRD in the proximal tubules (Figs. 1 and 2). One was large, palely eosinophilic, when stained with $\mathrm{HE}$, circumscribed round or oval droplets similar to the eosinophilic bodies in adult male rats ${ }^{6}$ and was filled with palely eosinophilic amorphous material or fine granules. The other was small, deeply eosinophilic, when stained with $\mathrm{HE}$ and unsharp with indistinct boundaries. Both types of droplets were in close proximity to each other in the proximal straight

Table 1. Incidence of Renal Protein Reabsorption Droplets in Beagle Dogs

\begin{tabular}{|c|c|c|c|c|c|c|c|c|c|c|}
\hline \multirow{2}{*}{$\begin{array}{c}\text { Age } \\
\text { (Month) }\end{array}$} & \multicolumn{5}{|c|}{ Male } & \multicolumn{5}{|c|}{ Female } \\
\hline & No. of Animals & + & H & \# & (苂) & No. of Animals & + & $\#$ & \# & (\%) \\
\hline $7-8$ & 5 & & 1 & & 20.0 & 5 & & & & 0 \\
\hline $9-11$ & 31 & 2 & 8 & 4 & 45.2 & 31 & & & & 0 \\
\hline $18-19$ & 32 & 2 & 3 & 6 & 34.4 & 34 & & & & 0 \\
\hline $20-21$ & 4 & & & 1 & 25.0 & 4 & & & & 0 \\
\hline $31-32$ & 4 & & 1 & & 25.0 & 4 & & & & 0 \\
\hline Total & 76 & 4 & 13 & 11 & 36.8 & 78 & 0 & 0 & 0 & 0 \\
\hline
\end{tabular}

Criteria for severity : + : Slight, \# : Moderate, \# : Marked. 


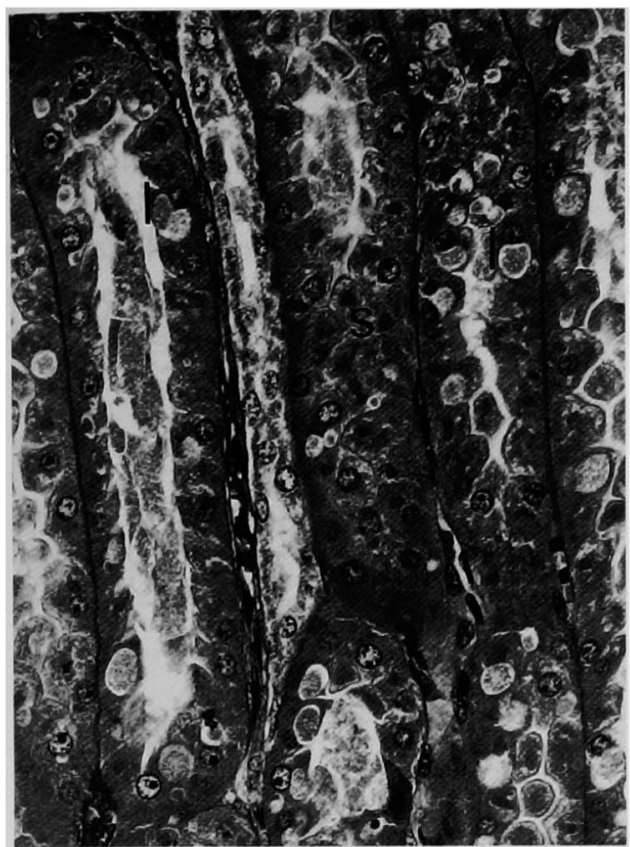

Fig. 1. PRD in the renal tubular cells. Large palely eosinophilic droplets (1) and small deeply eosinophilic droplets(s) are seen. The epithelial cells show swelling and nuclear enlargement. Nine months old male beagle dog. HE $\times 410$.

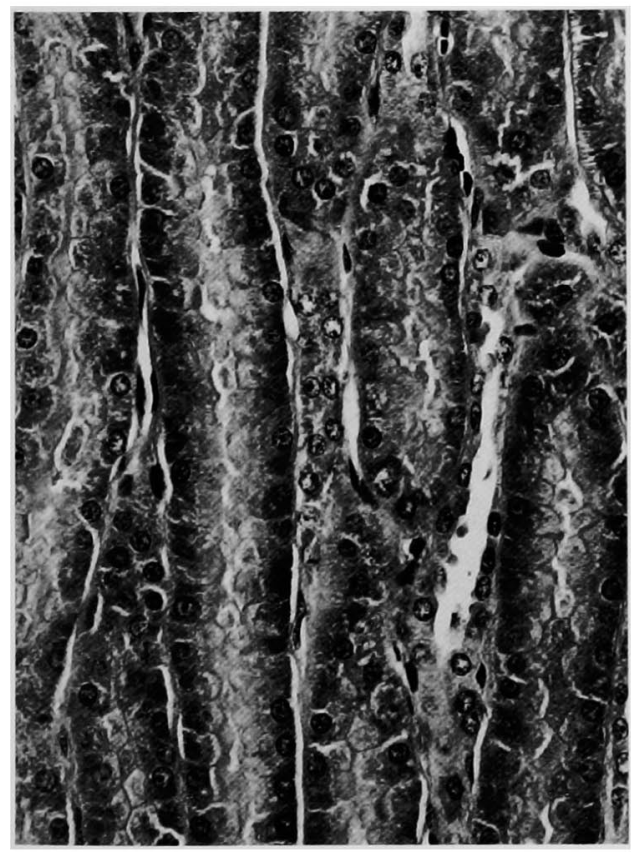

Fig. 2. No PRD were seen in the renal tubular cells. Ten months old female beagle dog. HE $\times 410$.

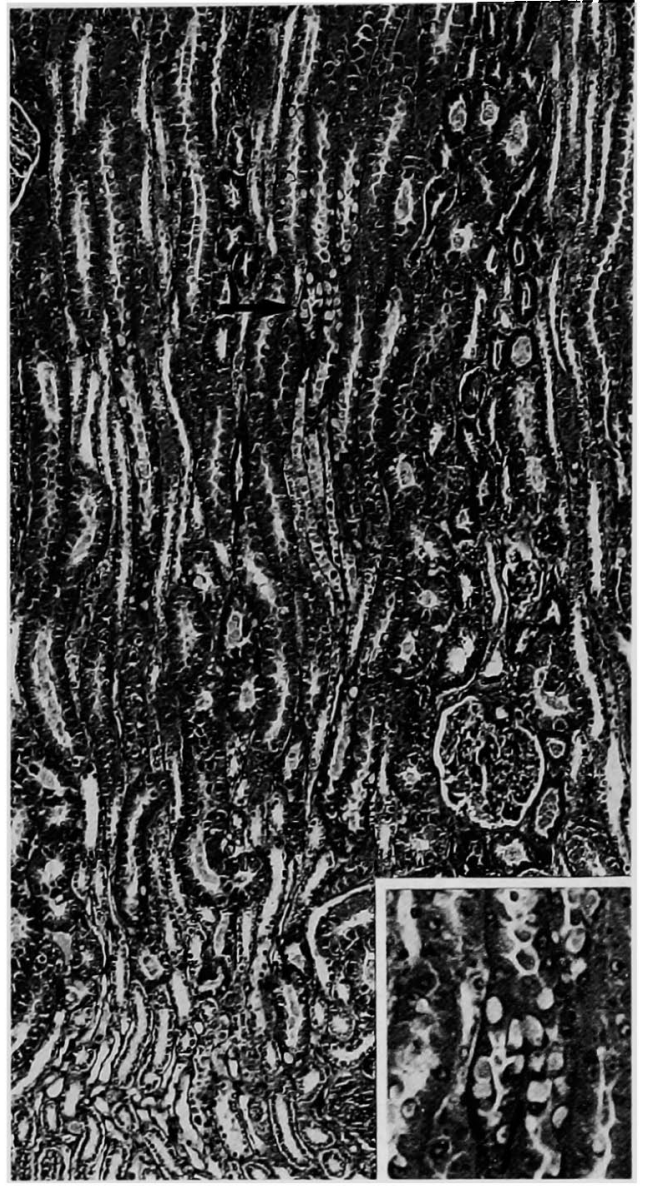

Fig. 3. Corticomedullary junction of the kidney. PRD (arrow) in the proximal straight tubules (P3 segment). Nine months old male beagle dog.

HE $\times 100$. Insert represents higher magnification of same animal. HE $\times 220$.

portion of the renal tubules; P3 segment (Figs. 3, 4 and 5). Each tubular epithelial cell with PRD contained one or two droplets. The epithelial cells with PRD showed swelling, eosinophilic cytoplasmic changes, and nuclear enlargement with prominent nucleoli (Fig. 1). Consequently, the renal tubules appeared thicker than normal. Some solitary necrotic cells were observed in the affected tubules. The basement membranes of the tubular epithelium with PRD were also slightly thickened. No specific glomerular changes were observed in the kidneys with PRD.

Histochemically, both types of droplets were stained negative for PAS, oil red 0, Sudan black B, Gram's, and Weigert's techniques. They were 


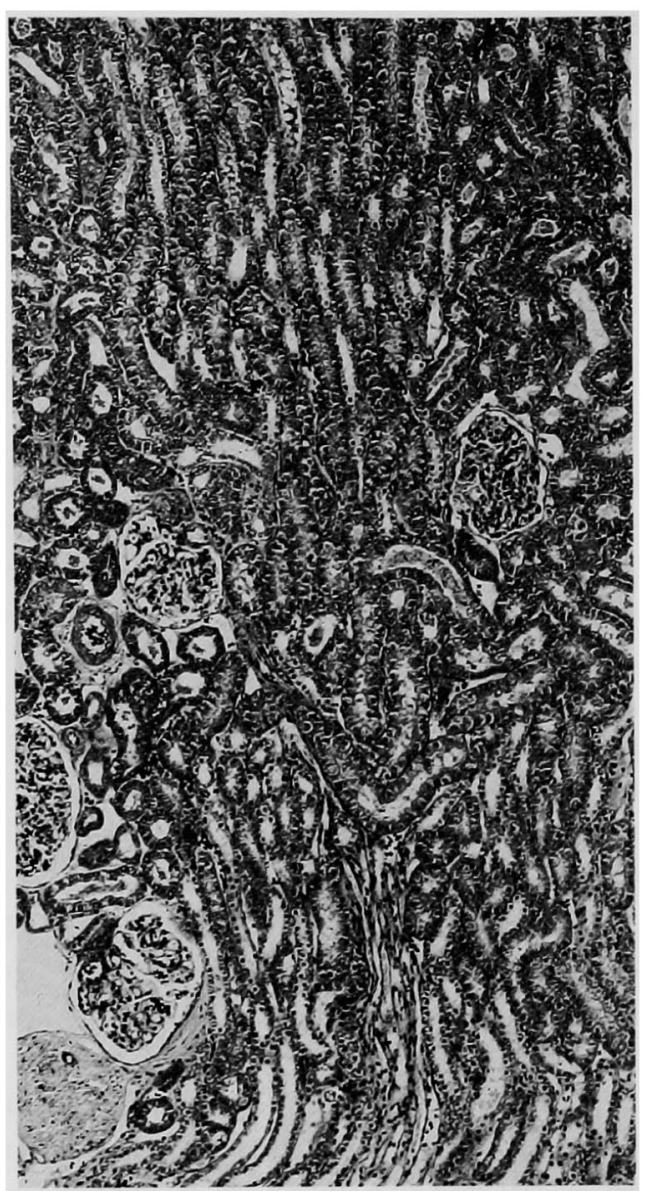

Fig. 4. Corticomedullary junction of the kidney. No PRD were seen in the renal tubular cells. Nine months old female beagle dog. HE $\times 100$.

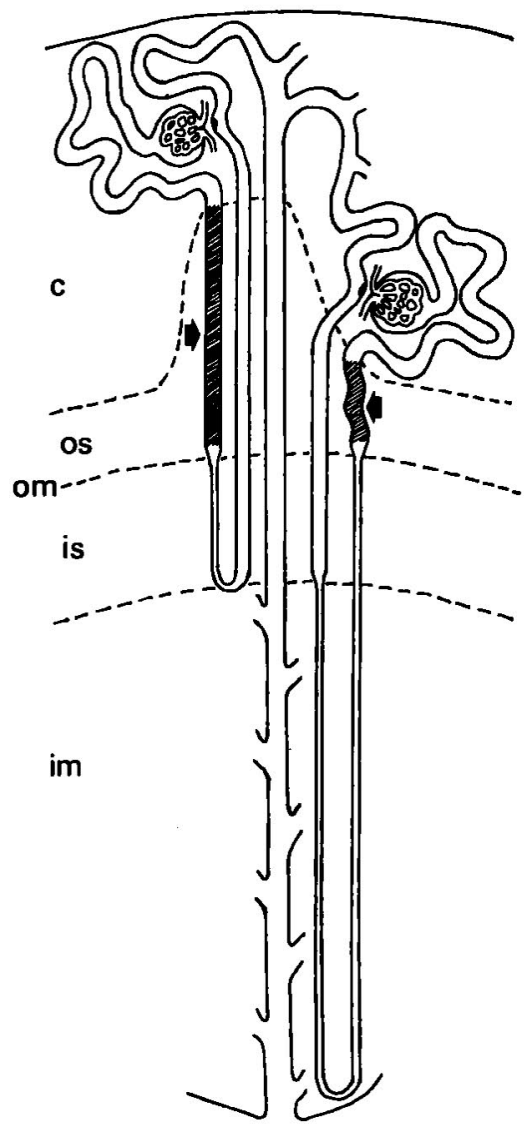

Fig. 5. Location of PRD in the nephron. PRD are found only in the proximal straight tubules, P3 segment (arrow). Zonal division of the kidney : cortex (c), outer medulla (om), outer stripe (os), inner stripe (is), and inner medulla (im). Crispin, SM, Stickland, NC (1983) ${ }^{40}$.

Table 2. Staining Response of Renal Protein Reabsorption Droplets in Beagle Dogs and Eosinophilic Bodies in Rats by Various Histochemical Techniques

\begin{tabular}{|c|c|c|c|}
\hline Staining & Species & Beagle Dog & Rat \\
\hline PAS & & - & -1 \\
\hline Oil Red O & & - & $-^{2}$ \\
\hline Sudan Black B & & - & -2 \\
\hline Fibrin & & - & -1 \\
\hline Masson & & Reddish Violet & ND \\
\hline Azan & & Grayish Blue & $\begin{array}{l}\text { Orange, Reddish Violet' } \\
\text { Red, Grayish Blue }{ }^{2}\end{array}$ \\
\hline
\end{tabular}

- : Negative

ND: No Data

1 : Kawai, S., Exp. Anim., 1980

${ }^{2}$ : Sugimoto, T. et al., 1985, Tokyo 
stained reddish-violet with Masson trichrome and grayish-blue with Heidenhein's azan techniques. AFOG staining revealed large, grayish-blue droplets and small reddish-violet droplets (Table 2).

Upon electron microscopic examination, large droplets appeared as vacuoles bounded by a single membrane in the cytoplasm of the proximal tubular cells (Fig. 6). They were filled with a uniform- ly electron lucent, proteinaceous fine, granular material. Most of the membrane was smooth, but some parts formed processes. The vacuoles also contained a few degenerated mitochondria and smooth endoplasmic reticulum (Fig. 6). Small droplets appeared as irregular clumps of electron lucent material without a boundary membrane (Fig. 7). They were composed of fine,

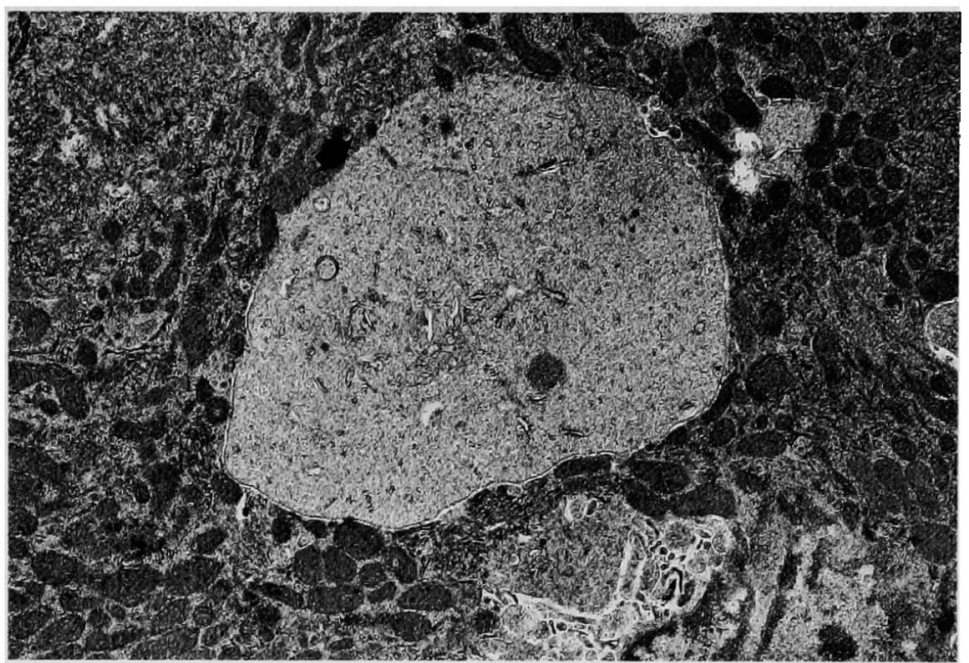

Fig. 6. Electron micrograph of the large droplet bounded with a single membrane (arrow) in a proximal tubular cell. It is filled with electron lucent, proteinaceous, fine granular material, and contains some organelles. $\times 12,000$.

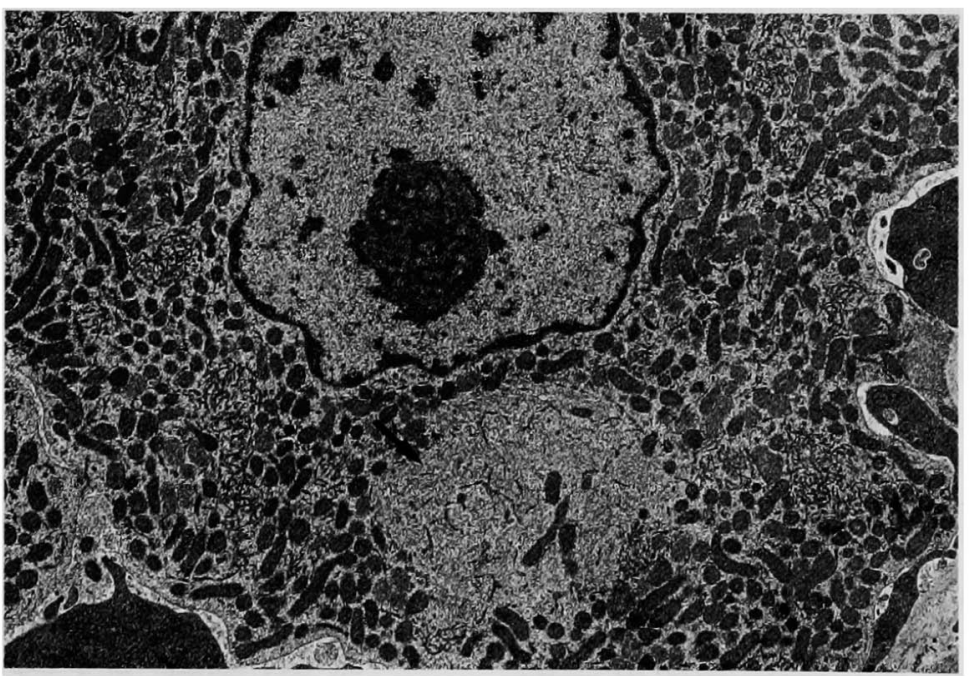

Fig. 7. Electron micrograph of a small droplet without a boundary membrane (arrow) in the proximal tubular cell. It is composed of electron lucent, proteinaceous, fine granular material, and contains some organelles as did the large droplets. $\times 8,100$. 
proteinaceous granules as were the large droplets and contained a few membranous structures similar to smooth endoplasmic reticulum. No specific glomerular changes were visible in the kidneys of all dogs examined electron microscopically.

\section{Discussion}

The histopathology of spontaneous PRD appearing in the renal tubular cells in beagle dogs was examined. Of particular interest is that this lesion was specific to male dogs and similar to eosinophilic body or hyaline droplet formation seen in the renal tubules of male rats. This maledog-specific PRD have never been reported. It is well known that adult male rats have two types of sex-dependent renal tubular PRD, hyaline droplets and eosinophilic bodies. The hyaline droplets are small, round and stain positive with PAS. The eosinophilic bodies, on the other hand, are large, palely eosinophilic, stain negative with PAS, Wiegert's, and fatty reaction ${ }^{6}$. The morphological features and reactivity to histochemical stains of the large droplets in the dogs resembled the eosinophilic bodies seen in male rats. The eosinophilic bodies and hyaline droplets in male rats appear in the proximal convoluted tubules (P2 segment) ${ }^{5-7}$. It is notable that the located of the PRD in $\operatorname{dog}(P 3$ segment) was different from that of rats. Stonard et $a l{ }^{20}$ suggested that the hyaline droplets in the rats are a result of the reabsorption of protein. These PRD in male dogs are probably the result of intense protein reabsorption by the tubular cells, because of the histological or ultrastructural similarity and response to various staining methods.

Ultrastructural evaluations showed it is not a secondary lysosome. It might, however, be a fused pinosome in the proximal tubular cells. The small droplets may be large droplets that have lost their boundary membrane.

It has been reported that spontaneous and chemically induced renal PRD are the result of accumulation of $\alpha 2 \mu$ in the lysosomes ${ }^{30,34,35,41}$. $\alpha 2 \mu$ is sex-dependent urinary protein secreted by the liver of adult male rats ${ }^{10-12}$; the synthesis of which is under multi-hormonal control of androgens, glucocorticoids, growth hormone, and thyroxine ${ }^{9,16.42}$. Male rats excrete 120 time more $\alpha 2 \mu$ in the urine than do females ${ }^{43,44}$. Because of its low-molecular-weight $(18,000-26,400 \mathrm{Da})$, $\alpha 2 \mu$ is freely filtered through the glomerulus ${ }^{15,44}$. Deficient catabolism of $\alpha 2 \mu$ in the lysosomes might also be a mechanism for the accumulation of $\alpha 2 \mu$ in renal tubules ${ }^{27}$. Loury et al ${ }^{45,46}$ suggested that hydrocarbons binding to $\alpha 2 \mu$ impedes its catabolism.

Olson et al. ${ }^{25,47}$ suggested that humans also possess urinary proteins which are products of the gene family coding for $\alpha 2 \mu$ in rats, including; $\alpha 1$-acid glycoprotein, $\alpha 1$-microglobulin, and plasma retinol-binding protein. Male beagle dogs with PRD in renal tubules have no glomerular changes. Therefore, they may also have a sex-dependent low-molecular-weight urinary protein, which is freely filtrated through the glomerulus, such as $\alpha 2 \mu$ in adult male rats. Considering the importance of $\alpha 2 \mu$ in male rats in extrapolating hydrocarbon-induced toxicity or carcinogenicity in male rats to humans; renal effect of toxicity induced by chemicals, and various renal diseases in the dog should be evaluated on the same basis, i.e., on the presence of a specific urinary protein in male beagle $\operatorname{dog} s^{48}$.

Acknowledgments : The authors would like to thank Dr. Nobuyuki Ito, Dr. Tomoyuki Shirai (First Department of Pathology, Nagoya City University Medical School), Dr. Tadaharu Kitagaki (Japan Seigiken Research Center), and Mr. Junichi Hashiguchi for their helpful suggestions and Mr. Takashi Hagiwara, Mrs. Yasuyo Ohba, Mrs. Mutsumi Katoh, Mrs. Sanae Yamamoto, and Mrs. Yoshiko Suzuki, Miss Reiko Murakoshi (Biosafety Research Center Foods, Drugs and Pesticides), and Mr. Kouji Muramatsu (Japan Seigiken Research Center) for their technical assistance.

We also thank Dr. William J. Tierney (Consultant in Toxicology, Pittstown, New Jersey, U.S.A.) for reviewing the manuscript.

\section{References}

1. Gruys, E : Renal pathology in domestic animals. In: Veterinary nephrology, Hall (ed). William Heinemann Medical Books Ltd., London, pp. 103137, 1983.

2. Logothetopoulos, J, and Weinbren, $\mathrm{K}$ : Naturally occurring protein droplets in the proximal tubule of the rat's kidney. $\mathrm{Br} J$ Exp Pathol 36: 402-406, 1955.

3. Oliver, J, Moses, MJ, MacDowell, MC, and Lee, YC: Cellular mechanisms of protein metabolism in 
the nephron. II. The histochemical characteristics of protein absorption droplets. J Exp Med 99 : 605-631, 1954.

4. Oliver, J, and MacDowell, M : Cellular mechanisms of protein metabolism in the nephron. VII. The characteristics and significance of the protein absorption droplets (hyaline droplets) in epidemic hemorrhagic fever and other renal diseases. J Exp Med 107: 731-767, 1958.

5. Alden, CL, Kanerva, RL, Ridder, G, and Stone, LC : The pathogenesis of the nephrotoxicity of volatile hydrocarbons in the male rat. In: Advances in Modern Environmental Toxicology, Volume VII. Renal Effects of Petroleum Hydrocarbons, MA Mehlman (ed). Princeton Scientific Publishers NJ. pp. 107-120, 1984.

6. Kawai, S : Report from working group on longterm holding of experimental animals. Exp Anim 29: 181-231, 1980.

7. Peter, CP, Burek, JD, and Zwieten, MJ : Spontaneous nephropathies in rats. Toxicol Pathol 14: 91 $100,1986$.

8. Kitchen, DN : Neoplastic renal effects of unleaded gasoline in Fischer 344 rats. In: Advances in Modern Environmental Toxicology, Volume VII. Renal Effects of Petroleum Hydrocarbons, MA Mehlman (ed). Princeton Scientific Publishers Inc., $\mathrm{NJ}$, pp. 65-71, 1984

9. Irwin, JF, Lane, SE, and Neuhaus, OW: Synergistic effect of glucocorticoids and androgens on the biosynthesis of a sex-dependent protein in the male rat. Biochim Biophys Acta 252: 328-334, 1971.

10. Neuhaus, OW, and Flory, W: Age-dependent changes in the excretion of urinary proteins by the rat. Nephron 22: 570-576, 1978.

11. Neuhaus, OW, and Lerseth, DS : Dietary control of the renal reabsorption and excretion of $\alpha 2 \mu$ globulin. Kidney Int 16: 409-415, 1979.

12. Neuhaus, OW, Flory, W, Biswas, $\mathrm{N}$, and Hollerman, CE : Urinary excretion of $\alpha 2 \mu$-globulin and albumin by adult male rats following treatment with nephrotoxic agents. Nephron 28: 133-140, 1981

13. Roy, AK, and Neuhaus, OW: Proof of the hepatic synthesis of a sex-dependent protein in the rat. Biochim Biophys Acta 127: 82-87, 1966.

14. Roy, AK, and Neuhaus, OW: Identification of rat urinary proteins by zone and immunoelectrophoresis. PSEBM 121 : 894-899, 1966.

15. Roy, AK, Neuhaus, OW, and Harmison, CR : Preparation and characterization of a sex-dependent rat urinary protein. Biochim Biophys Acta 127: 72$81,1966$.

16. Roy, AK, and Neuhaus, OW : Androgenic control of a sex-dependent protein in the rat. Nature 214: 618-620, 1967.

17. Short, BG, Burnett, VL, and Swenberg, JA : Elevated proliferation of proximal tubule cells and localization of accumulated $\alpha 2 \mu$-globulin in F344 rats during chronic exposure to unleaded gasoline or 2, 2, 4-trimethylpentane. Toxicol Appl Pharmacol 101 : 414-431, 1989.
18. Sippel, AE, Feigelson, P, and Roy, AK : Hormonal regulation of the hepatic messenger RNA levels for $\alpha 2 \mu$ globulin. Biochemistry 14: 825-829, 1975.

19. Stonard, MD, Phillips, PGN, Foster, JR, Simpson, MG, and Lock, EA : $\alpha 2 \mu$-globulin : Measurement in rat kidney following administration of 2,2,4 trimethylpentane. Toxicology $41: 161-168,1986$.

20. Stonard, MD, Phillips, PGN, Foster, JR, Simpson, MG, and Lock, EA : $\alpha 2 \mu$-globulin : Measurement in rat kidney and relationship to hyaline droplets. Clin Chim Acta 160 : 197-203, 1986.

21. Busey, WM, Cockrell, BY : Non-neoplastic exposure-related renal lesions in rats following inhalation of unleaded gasoline vapors. In : Advances in Modern Environmental Toxicology, Volume VII. Renal Effects of Petroleum Hydrocarbons, MA Mehlman (ed), Princeton Scientific Publishers Inc., NJ, pp. 57-64, 1984.

22. Halder, CA, Warne, TM, Hatoum, NS : Renal toxicity of gasoline and related petroleum naphthas in male rats. In : Advances in Modern Environmental Toxicology, Volume VII. Renal Effects of Petroleum Hydrocarbons, MA Mehlman(ed). Princeton Scientific Publishers Inc., NJ, pp. 73-88, 1984.

23. MacFarland, HN, Path, FRC: Xenobiotic induced kidney lesions: Hydrocarbons the 90-day and 2year gasoline studies. In: Advances in Modern Environmental Toxicology, Volume VIl. Renal Effects of Petroleum Hydrocarbons, MA Mehlman (ed). Princeton Scientific Publishers, Inc., NJ, pp. $51-56,1984$.

24. Murty, CVR, Olson, MJ, Garg, BD, and Roy, AK : Hydrocarbon-induced hyaline droplet nephropathy in male rats during senescence. Toxicol Appl Pharmacol 96: 380-392, 1988.

25. Olson, MJ, Garg, BD, Murty, CVR, and Roy, AK : Accumulation of $\alpha 2 \mu$-globulin in the renal proximal tubules of male rats exposed to unleaded gasoline. Toxicol Appl Pharmacol 90: 43-51, 1987.

26. Phillips, RD, and Cockrell, BY: Effect of certain light hydrocarbons on kidney function and structure in male rats. In: Advances in Modern Environmental Toxicology, Volume VII. Renal Effects of Petroleum Hydrocarbons, MA Mehlman (ed). Princeton Scientific Publishers, Inc., NJ, pp. 89-105, 1984.

27. Swenberg, JA, Short, B, Borghoff, S, Strasser, J, and Charbonneau, $M$ : The comparative pathobiology of $\alpha 2 \mu$-globulin nephropathy. Toxicol Appl Pharmacol 97 : 35-46, 1989.

28. Alden, CL : A review of unique male rat hydrocarbon nephropathy. Toxicol Pathol 14: 109-111, 1986.

29. Kanerva, RL, McCracken MS, Alden CL, and Stone LC : Morphogenesis of decalin-induced renal alterations in the male rat. Food Chem Toxic 25: 53-61, 1987.

30. Kanerva, RL, Ridder, GM, Stone, LC, and Alden, $C L$ : Characterization of spontaneous and decalininduced hyaline droplets in kidneys of adult male rats Food Chem Toxic 25: 63-82, 1987. 
31. Burner, RH : Pathologic findings in laboratory animals exposed to hydrocarbon fuels of military interest. In : Advances in Modern Environmental Toxicology, Volume VII. Renal Effects of Petroleum Hydrocarbons, MA Mehlmen (ed). Princeton Scientific Publishers Inc., NJ, pp. 133-140, 1984.

32. MacNaughton, MG, Uddin, DE: Toxicology of mixed distillate and high-energy synthetic fuels. In: Advances in Modern Environmental Toxicology, Volume VII. Renal Effects of Petroleum Hydrocarbons, MA Mehlman (ed). Princeton Scientific Publishers, Inc., NJ, pp. 121-132, 1984.

33. Charbonneau, M, Strasser, J, Lock, EA, Turner, MJ, and Swenberg, JA: Involvement of reversible binding to $\alpha 2 \mu$-globulin in 1,4-chlorobenzene-induced nephrotoxicity. Toxicol Appl Pharmacol 99 : 122 $132,1989$.

34. Lehman-Mckeeman, LD, Rivera-Torres, MI, and Caudill, D: Lysosomal degeneration of $\alpha 2 \mu$ globulin and $\alpha 2 \mu$-globulin-xenobiotic conjugates. Toxicol Appl Pharmacol 103 : 539-548, 1990.

35. Charbonneau, M, Lock, EA, Strasser, J, Cox, MG, Turner, MJ, and Bus, JS : 2, 2, 4-trimethylpentaneinduced nephrotoxicity 1 . Metabolic disposition of TMP in male and female Fischer 344 rats. Toxicol Appl Pharmacol 91 : 171-181, 1987.

36. Lock, EA, Charbonneau, M, Strasser, J, Swenberg, JA, and Bus, JS : 2, 2, 4-trimethylpentane-induced nephrotoxicity II. The reversible binding of a TMP metabolite to a renal protein fraction containing $\alpha 2 \mu$-globulin. Toxicol Appl Pharmacol 91 : 182192. 1987.

37. Goldsworthy, TL, Lyght, O, Burnett, VL and Popp, JA : Potential role of $\alpha 2 \mu$-globulin, protein droplet accumulation, and cell replication in the renal carcinogenicity of rats exposed to trichloroethylene. perchloroethylene, and pentachloroethane. Toxicol Appl Pharmacol 96 : 367-379, 1988.

38. Loury, DJ, Smith-Oliver, T, Strom, S, Jirtle, R, Michalopoulos, G, and Butterworth, BE: Assessment of unscheduled and replicative DNA synthesis in hepatocytes treated in vivo and in vitro with unleaded gasoline or 2,2,4-trimethylpentane. Tox- icol Appl Pharmacol 85 : 11-23, 1986.

39. Short, BG, Burnett, VL, Cox, MG, Bus, JS, and Swenberg, JA: Site-specific renal cytotoxicity and cell proliferation in male rats exposed to petroleum hydrocarbons. Lab Invest 57 : 564-577, 1987.

40. Crispin, SM, Stickland, NC: Gross and microscopic anatomy of the mammalian kidney. In : Veterinary nephrology, Hall (ed). William Heinemann Medical Books Ltd., London, pp. 7-25, 1983.

41. Stone, LC, Kanerva, RL, Burns, JL, and Alden, CL: Decaline-induced nephrotoxicity: Light and electron microscopic examination of the effects of oral dosing on the development of kidney lesions in the rat. Food Chem Toxic 25 : 43-52, 1987.

42. Kurtz, DT, Sippel, AE, and Feigelson, P : Effect of thyroid hormones on the level of the hepatic mRNA for $\alpha 2 \mu$ globulin. Biochemistry 15: 1031-1036, 1976.

43. Lane, SE, and Neuhaus, OW : Multiple forms of $\alpha 2 \mu$, a sex-dependent urinary protein of the adult male rat. Biochim Biophys Acta 263: 433-440, 1972.

44. Vandoren, G, Mertens, B, Heyns, W, Van Baelen, HV, Rombauts, W, and Verhoeven, G : Different forms of $\alpha 2 \mu$-globulin in male and female rat urine. Eur J Biochem 134: 175-181, 1983.

45. Borgghoff, SJ, Miller, AB, Bowen, JP, and Swenberg, JA : Characteristics of chemical binding to $\alpha 2 \mu$ globulin in vitro evaluating structure-activity relationships. Toxicol Appl Pharmacol 107: 228-238, 1991.

46. Loury, DJ, Smith-Oliver, T, and Butterworth, BE : Assessment of the covalent binding potential of 2, 2 , 4-trimethylpentane of rat $\alpha 2 \mu$-globulin. Toxicol Appl Pharmacol 88 : 44-56, 1987.

47. Olson, MJ, Johnson, JT, and Reidy, CA : A comparison of male rat and human urinary proteins : implications for human resistance to hyaline droplet nephropathy. Toxicol Appl Pharmacol 102: 524536, 1990.

48. Robertson, JL : Spontaneous renal disease in dogs. Toxicol Pathol 14: 101-108, 1986. 